\title{
Effort to Develop Children's Cognitive Aspect in Showing Exploratory and Probing Activities Using Experimental Method and Make A Match Model
}

Putri Inderianty*

Department of Early Childhood Education, Universitas Lambung Mangkurat, Banjarmasin, Indonesia.

\begin{tabular}{|c|c|}
\hline ARTICLE INFO & A B STRACT \\
\hline \multirow{2}{*}{$\begin{array}{l}\text { Received: 09-03-20I7 } \\
\text { Revised: 08-05-20I7 } \\
\text { Accepted: 07-06-20I7 } \\
\text { Keywords: } \\
\text { Cognitive, exploratory, } \\
\text { experimental, make a } \\
\text { match model }\end{array}$} & $\begin{array}{l}\text { This research aims to describe the implementation and to develop the cognitive } \\
\text { aspects of children through activities that show exploratory and probing activities by } \\
\text { using experimental design and make a match model. This research is classroom action } \\
\text { research with subjects were children in group B RA Raudhatul Jannah Banjarmasin } \\
\text { academic year of } 2015 / 2016,2 \text { nd semester. The results showed that experimental } \\
\text { method and make a match model can develop children's cognitive abilities. }\end{array}$ \\
\hline & $\begin{array}{l}\text { (c) } 2018 \text { The Authors. Journal of K6, Education, and Management (j-K6EM). ISSN: } 2580-2135 . \\
\text { Published by Graduated Program of Educational Management, Universitas Lambung } \\
\text { Mangkurat, Banjarmasin, Indonesia. This is an open access article under the open journal } \\
\text { systems. }\end{array}$ \\
\hline
\end{tabular}

*Author correspondence: Putri Inderianty; E-mail: putri.inderianty@gmail.com 


\section{Introduction}

Education is an effort to humanize the human beings. It means that educational process it is expected to create better human beings. A good human standard differs across the communities, nations or countries because of the different point of view of nation so that it will bring a difference in the orientation or educational goals.

According to the observation conducted on Monday, February I5, 2016 on group B in RA Raudhatul Jannah JLN Sungai Miai Dalam Banjarmasin of the academic year of 20I4/20I5 on learning, it showed exploratory and probing activities, i.e. from 18 children consisting of 9 boys and 9 girls who are able to demonstrating the exploratory and probing activities appropriately was only (I6\%) or 3 children develops very well while (16\%) or 3 children develops as expected and $(22 \%)$ or 4 children begin developing and ( $44 \%$ ) or 8 children not yet developed showing the exploratory and probing activity.

This is because during the lesson, the children pay a little attention to the teacher, lack of confidence, less focus on the lesson, and also the implementation of learning models using fewer interesting media and limited in the implementation of the learning. So that the children are confused, passive, silent and mistaken in showing, searching and doing the science learning activities that are exploratory and probing given to them.

If this matter is neglected, it will affect the thinking sensitivity of the children in demonstrating exploratory and probing activities and this will not develop properly as well. It will also have an impact on the children education in the elementary school level both in terms of enrolling to a quality elementary school or competing locally, nationally and internationally.

To overcome these problems, the researcher searched for the appropriate strategy in the cognitive learning process showing the exploratory and probing activities so that the children can be directly involved in learning and the learning activities will be more fun. Moreover, to achieve the optimal results was by using experimental method and make a match model.
According Piaget especially for early childhood, knowledge can be acquired through exploration because by exploring, the children can build their knowledge through activities they are doing (Suyadi, 20I0).

The experimental method is one way of presenting the lesson in which the children doing experiments by experiencing and proving something, they learned by themselves. In the teaching and learning process using this experimental method, the children are given the opportunity to experience or doing it themselves, following a process, observing an object, analyzing, proving and drawing conclusions on objects, states, or processes. Therefore, the children are required to experience themselves, seek the truth, or try to find out, and draw conclusions about the process they experienced (Djamarah \& Zain, 2013).

Make a match learning model is one of the cooperative learning models in which the children are required to find the matching pair of the question card obtained through random drawing. Basically, it is distributed to the children by the teacher (Miftahul, 20I4).

\section{Methodology}

A good methodology should bring the researcher to achieve the objective (Dalle, 20I0; Dalle et al., 20I7; Derlina et al., 20I8). Qualitative approach is data information in the form of sentences that gives an idea of the children expressions related to their level of understanding of a subject (Kunandar, 2012).

Classroom action research is an attempt to observe the learning activities of a group of learners by providing treatment which is purposively produced. The action is performed by the teachers together with the learners under the guidance and direction of the teachers in order to improve and develop the quality of learning (Mulyasa, 2013).

Classroom Action Research can be interpreted as an effort or action performed by the teacher or the researcher to solve the learning problem through research activity. This research was conducted by changing habits (e.g. method, strategy, media) in the learning activity (Wahidmurni, 2008). 
In accordance with the type of research selected, which is classroom action research, this study used spiral classroom action research model proposed by Kemmis and Mc. Tanggart that is cyclic from one to another cycle. Every cycle includes: Planning, Acting, Observing, and Reflecting.

The data collection in this study includes: (I) Data about teacher's activities in the learning process by experimental method and make a match model, (2) data about children's activity during the learning activity shows exploratory and probing activity using experimental method of make a match model, (3) data of children learning result about developing cognitive aspect showing the exploratory and probing activity using experimental method of make a match model.

Data analysis techniques used in this classroom action research included qualitative and quantitative analysis. (I) Qualitative analysis related to teacher and children activities during the learning process showing exploratory and probing activity using experimental method of make a match model (2) Quantitative Analysis related to learning activity results of the children of group $B$ RA Raudhatul Jannah JLN Sungai Miai Dalam Banjarmasin in showing exploratory and probing activity.

Analysis of the children learning results were: the results of cognitive development of the children showing exploratory and probing activity using experimental methods and make a match model by observing and assessing the children learning results from each aspect studied namely, attention, participation, courage, discipline and accuracy in answering questions during the learning activities indicate the exploratory and probing activity. The assessment format used symbols and the results of the assessment were as follows: not yet developed children in accordance with expected indicators in the previous daily activity plan, were given a star, Children who have begun to develop in accordance with the expected indicators in the previous daily lesson plan, were given two stars. Children who are developing according to the expectations on the expected indicators in the daily lesson plan got three stars. Well-developed children exceeding the expected indicator in daily lesson plan got four stars.

\section{Results and Discussions}

In this study, the learning process used was experimental method and make a match model. The implementation of this research was conducted by observing in which the children were given the opportunity to experience and prove something they learned or obtained during the experiment. After the child experiencing themselves, they were invited to play make a match where in the game the children were invited to look for the pair of the question card with the answer card by using a picture card by facing each other with different child with different cards so on until all the children can find the card pair correctly.

There are 3 indicators of the data of the research result: I) the ability of the children to try and tell what happens if the colors are mixed. 2) the ability of the children to try and tell what happens if the objects are put into the water. 3 ) the ability of the children to try and tell what happens if the balloon is blown and then released.

The steps of the experimental method are as follows: I) The teacher explains the purpose of the experimental activity; 2) The teacher provides the tools and materials to be used; 3) The teacher monitors the children while doing the experiments and provides suggestions and asks questions; 4) The teacher collects the results from the experimental activities and concludes (Putra, 2013).

The steps for make a match model are: I) The teacher prepares several cards with relevant concepts or topics for the review session; 2) every student thinks the answer of the pairing card; 3 ) every student looks for a partner who has the matching card; 4) every student can match the card before the time is up; 5) every student who can match the card before the time limit is given a point; 6) after one round, the cards is shuffled so every student can get different card from the previous round; 7) The teacher concludes (Shoiman, 2013).

The steps of the experimental method and the make a match model are as follows: The teacher explains the purpose of the experimental activity; 2) The teacher provides the tools and materials to be used; 3) The teacher monitors the children while doing the experiments and provides suggestions and asks questions; 4) The teacher collects the results from the experimental activities and concludes (Putra, 20I3). 
The steps for make a match model are: I) The teacher prepares several cards with relevant concepts or topics for the review session; 2) every student thinks the answer of the pairing card; 3 ) every student looks for a partner who has the matching card; 4) every student can match the card before the time is up; 5) every student who can match the card before the time limit is given a point; 6) after one round, the cards is shuffled so every student can get different card from the previous round; 7) The teacher concludes. As a teaching planner, the teacher should prepare the material to be delivered, how to deliver it and what media to use before teaching.

With the experimental method and make a match model, this learning process will be more meaningful because the children are directly involved in the learning and it will be more fun because after the children doing the experiments the children are invited to play make a match in order to repeat the learning that has been done so that the learning will be more fun. This is indeed very useful for the children for the next or the following process.

From the above explanation, on the teacher activity cycle I Meeting I got a score of 38 with good category, cycle I meeting 2 was increased by getting score of 45 with good category and on cycle II meeting I was increased more to score 53 and has reached the established indicator with excellent category. The results of the development of the children's cognitive aspect based on the results of the development of cognitive abilities of children in showing exploratory and probing activities are: in the cycle I meeting I, it can be seen that I child got score $(\star)$, 7 children got score $(\star \star)$, there are 6 children got $(\star \star \star)$, and 4 children got $(\star \star \star \star)$. Finally, it can be said that the result of the percentage of undeveloped children was $56 \%$ and the developed children was $44 \%$. This shows that the results of cognitive development of children in the cycle I meeting $\mathrm{I}$ is included in the category of began to develop because many children have not achieved the individual success indicators of $\geq 80 \%$. So, it is indicated that the development of the cycle I meeting I was in the criteria began to develop. In addition to that, there should be repair and improvement in the next cycle.

In the cycle I meeting 2 , it can be seen that there are 2 children who got score of $(\star), 3$ children got $(\star \star), 7$ children got score of $(\star \star \star)$, and 6 children got $(\star \star \star \star)$. So it can be said that the percentage results of the undeveloped children were $28 \%$ and developed children was $72 \%$. This shows that the results of cognitive development of children in the cycle I meeting 2 is included in the category of began to develop because many of them have not achieved the individual success indicators of $\geq 80 \%$. So, the development in cycle I meeting I was in the criteria of developing as expected. In addition to that, there should be repair and improvement in the next cycle.

In the cycle II meeting I, none score $(\star), 2$ children score $(\star \star)$, 4 children score $(\star \star \star)$, and I2 score $(\star \star \star \star)$. So, it can be said that the percentage fulfills the individual success indicator of $\geq 80 \%$, with only 2 children got 2 stars with the percentage of $I I \%$ and $I 7$ children who develop as expected with the percentage of $89 \%$, then the development of cycle II Meeting I is in the criteria of well-developed child.

\section{Conclussion and Recomendations}

The conclusion are (I) Teacher activity in cognitive aspect showing exploratory and probing activity using Experimental method and Make A Match Model performed very well; (2) The children showed exploratory and probing activity during the cognitive learning using Experimental method and Make A Match improved very well and active; (3) The results of the development of children cognitive abilities in learning showing exploratory and probing activities using Experimental methods and Make A Match Model indicated improvement and was performed well and fulfilled the category of excellent developed.

The recommendations are (I) It is expected that teachers use experimental model of experimental method and make a match model as an alternative to implement, providing variation in teaching and learning process for developing the cognitive ability of the children showing exploratory and probing activities; (2) For the principle, tt is suggested to provide an introduction in teaching by providing guidance and reference to all teachers in using the teaching models showing exploratory and probing activities in order to improve the quality of teachers in learning process; (3) For the Researchers Hopefully, they can be utilized the results of this study at its best and can apply it for 
the benefit of education to improve the quality of education.

\section{Acknowledgment}

No acknowledgment

\section{References}

Dalle, J. (20I0). Metodologi umum penyelidikan reka bentuk bertokok penilaian dalaman dan luaran: Kajian kes sistem pendaftaran siswa Indonesia. Thesis PhD Universiti Utara Malaysia.

Dalle, J., Hadi, S., Baharuddin., \& Hayati, N. (20I7). The Development of Interactive Multimedia Learning Pyramid and Prism for Junior High School Using Macromedia Authorware. The Turkish Online Journal of Educational Technology, November. 7I4-72I.

Dalmono, M. (2010). Psikologi pendidikan. Jakarta: Rineka Cipta

Derlina., Dalle, J., Hadi, S., Mutalib, A.A., \& Sumantri, C. (2018). Signaling Principles in Interactive Learning Media through Expert's Walkthrough. Turkish Online Journal of Distance Education (TOJDE). I9(4), I47-I62

Djaramah, B.S. (2013). Strategi belajar mengajar. Jakarta: PT Rineka Cipta

Kunandar. (2012). Langkah-langkah mudah penelitian tindakan kelas. Jakarta: Raja Grafindo Persada.

Mulyasa. (2009). Praktik penelitian kelas. Bandung: PT Remaja Rosdakarya.

Putra, R.S. (2013). Desain belajar mengajar kreatif berbasis sains. Yogyakarta.: Data Press

Sanjaya, W. (2012). Penelitian tindakan kelas. Jakarta: Kencana.

Shoimin. (2014). 68 model pembelajaran inovatif dalam kurikulum 20I3. Yogyakarta: AR-Ruzz Media

Suyadi. (20I0). Psikologi belajar paud. Jakarta: PT Pustaka Insan Madani.

Wahidmurni., \& Ali, N. (2008). Penelitian tindakan kelas pendidikan agama dan umum dari teori menuju praktik. Malang: UM Press. 
ISSN 2580-2135 